\title{
HER2/neu, Topoisomerase 2a, Estrogen and Progesterone Receptors: Discordance between Primary Breast Cancer and Metastatic Axillary Lymph Node in Expression and Amplification Characteristics
}

\author{
Beyhan Ataseven ${ }^{\mathrm{a}} \quad$ Daniela Gologan ${ }^{\mathrm{a}} \quad$ Angela Gunesch $^{\mathrm{a}} \quad$ Victoria Kehl $^{\mathrm{b}}$ \\ Bernhard Hoegel $^{c} \quad$ Michaela Beer $^{c}$ Wolfgang Eiermann ${ }^{a}$ \\ ${ }^{a}$ Rotkreuzklinikum-Frauenklinik München, \\ ${ }^{b}$ Institut für medizinische Statistik und Epidemiologie, Technische Universität München, \\ ${ }^{\mathrm{c}}$ Pathologie München, Germany
}

\section{Keywords}

Breast Cancer - Metastasis - Hormone receptor .

HER2/neu - Topoisomerase 2a

\section{Summary}

Molecular classification of breast cancer (BC) and the evaluation of new biological markers such as estrogen receptor (ER), progesterone receptor (PR), ErbB2 (HER2) and topoisomerase $2 a$ (Topo2a) status are claimed to be important parameters in the management of $\mathrm{BC}$ therapy. In case of heterogeneity between primary $\mathrm{BC}$ and metastatic site, this implies profound limitations of efficient systemic therapy. Therefore, it is essential to analyze whether biological markers of $\mathrm{BC}$ relate to identical expression profiles of metastatic lymph nodes (mLNs). We used paraffin-embedded tumor tissue from 119 patients with at least $1 \mathrm{mLN}$. Immunohistochemistry (IHC) was used to analyze ER, PR, HER2 and Topo2a. In addition, HER2 and Topo2a amplification was evaluated by fluorescence/chromogenic in situ hybridization ( $\mathrm{FISH} / \mathrm{CISH}$ ) in all samples with a HER2 score of $2+/ 3+$ by IHC. Overall, the percentage of discordant marker status in the $\mathrm{BC}$ and its $\mathrm{mLN}$ was $2.6 \%$ for $\mathrm{ER}, 3.5 \%$ for $\mathrm{PR}, 3.4 \%$ for HER2, and $3.4 \%$ for Topo2a. With $\mathrm{FISH} / \mathrm{CISH}$, the amplification rate for Topo2a and HER2 was concordant in all cases. Because there are no prospective studies, it remains unclear whether these discrepancies have an effect on patient survival.

Presented in part as oral presentation on the 10th Nottingham International Breast Cancer Conference, 18-20 September 2007

\author{
Schlüsselwörter \\ Brustkrebs - Metastase - Hormonrezeptor - HER2/neu • \\ Topoisomerase 2a
}

\section{Zusammenfassung}

Zur Festlegung der Systemtherapie beim Mammakarzinom ist die Evaluation von biologischen Markern wie dem Östrogenrezeptor (ER), dem Progesteronrezeptor (PR), ErbB2 (HER2) und Topoisomerase 2a (Topo2a) essenziell. Im Falle einer bestehenden Heterogenität zwischen dem Primärtumor der Mamma (BC) und der Metastase bedeutet dies eine starke Einschränkung in der effektiven Systemtherapie. Deshalb ist es wichtig zu analysieren, ob biologische Marker des BC mit identischen Expressionsprofilen von metastatischen Lymphknoten ( $\mathrm{mLNs}$ ) in Verbindung gebracht werden können. In unserer Studie wurden Paraffinblöcke von 119 BCs und jeweils mindestens einem ipsilateralen axillären $\mathrm{mLN}$ eingeschlossen. Mittels Immunhistochemie (IHC) wurden ER, PR, HER2 und Topo2a im Hinblick auf Diskordanz untersucht. Zusätzlich wurden HER2 und Topo2a bei allen IHC-Proben mit dem Ergebnis HER2 2+/3+ mittels Fluoreszenz-in-situ-Hybridisierung (FISH) und chromogener In-situ-Hybridisierung (CISH) untersucht. Zusammenfassend zeigte sich eine Diskordanz von 2,6\% für ER, 3,5\% für PR, 3,4\% für HER2 und 3,4\% für Topo2a zwischen $\mathrm{BC}$ und $\mathrm{mLN}$. Für HER2 und Topo2a waren die Amplifikationsraten von $\mathrm{FISH}$ und $\mathrm{CISH}$ in allen untersuchten Fällen konkordant. Da es bisher keine prospektiven Studien gibt, bleibt unklar, ob diese Diskrepanzen einen Einfluss auf das Überleben der Patienten haben.

\section{KARGER \\ Fax +497614520714 \\ Information@Karger.de}

www.karger.com (c) 2012 S. Karger GmbH, Freiburg

$1661-3791 / 12 / 0076-0465 \$ 38.00 / 0$

Accessible online at:

www.karger.com/brc 


\section{Introduction}

Estrogen receptor (ER), progesterone receptor (PR), and human epidermal growth factor receptor 2 (HER2) are therapeutically and prognostically important markers in the management of breast cancer (BC). Expression of hormone receptors is associated with better prognosis and important in predicting the response to adjuvant endocrine therapy $[1,2]$. Also, HER2 overexpression seems to be correlated with increased sensitivity to anthracyclin-based adjuvant chemotherapy [3-5]. Topoisomerase 2a (Topo2a) is the target enzyme for anthracyclines and there is a direct correlation between the cellular level of Topo2a and the dose of anthracycline cytotoxicity [6]. The report that Topo2a is frequently coamplified with HER2 in BC because of the proximity on chromosome 17q12-q21 provides a mechanism for the link between HER2 overexpression and anthracycline response [7]. Topo2a coamplification was seen in $35.4 \%$ of HER2-positive tumors, whereas no Topo2a amplification was detected in the HER2-normal population $(\mathrm{n}=1614)$; the deletion rate was $3 \%$ [8]. Because of this fact, some leading commentators came to the conclusion that HER2-normal patients should not receive anthracyline-based chemotherapy. Presently, assessment of biological markers with potential predictive value is performed only on the primary tumor. An examination of the corresponding lymph node (LN) as the first step of tumor progression is not routinely performed. However, the main goal of BC therapy is to prevent tumor progression and metastasis; inevitably, it is assumed that micrometastases already exist at the time of diagnosis $[9,10]$. But several studies suggest that the receptor status of metastatic lesions may change in relevant ranges. Discordance rates between $18-54 \%$ for hormonal receptors [11-13] and between $0-34 \%$ for HER2 [14-19] have been reported. Therefore, it is crucial to know how frequently these markers are discordant in $\mathrm{BC}$ and the ipsilateral metastatic LN (mLN). In this retrospective study, we analyzed the stability of ER, PR, HER2 and Topo2a of $\mathrm{BC}$ and the paired ipsilateral $\mathrm{mLN}$.

\section{Patients and Methods}

\section{Patients}

From the Redcross hospital Munich, 119 node-positive BC patients (median age 58 years, range 34-91 years) treated during the period from December 1999 to April 2002 were selected. All patients underwent stage-adapted breast surgery and axillary node dissection with tissue selection in 1 session, so that there were no influence factors, e.g. systemic therapy or radiotherapy. A brief schedule of the trial is given in figure 1 .

\section{Fixation Protocol and Hybrid Block Generation}

For each patient, paraffin cores of $0.6 \mathrm{~mm}$ in diameter were taken from representative regions of the $\mathrm{BC}$ and the corresponding $\mathrm{mLN}$ and precisely arrayed into a new recipient paraffin block using biopsy punches (PFM AG, Cologne, Germany). After fixation (12 h) in 4\% neutral-buffered formalin, tissues were paraffin embedded using a processor (GMI, Eden Prairie, MN, USA). After preparation, the hybrid blocks were

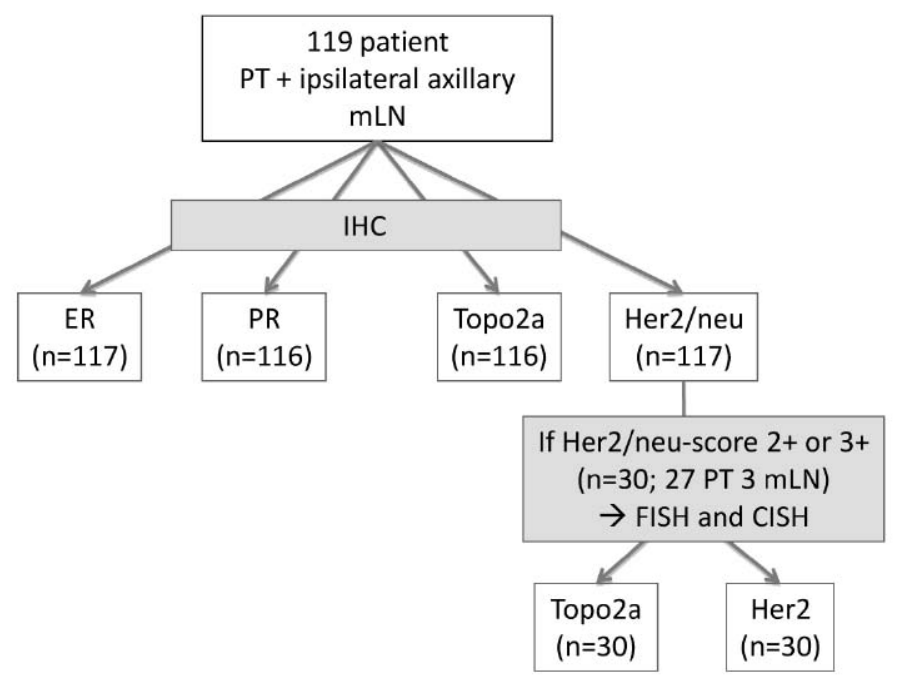

Fig. 1. Study trial schedule. PT: primary tumor; $\mathrm{mLN}$ : lymph node metastasis; ICH: immunohistochemistry; ER: estrogene receptor; PR: progesterone receptor; Topo2a: tomoisomerase 2a status; Her2/neu: ErbB2.

stained with hematoxylin and eosin (H\&E; Merck, Darmstadt, Germany) to ensure that sufficient tumor tissue was represented.

\section{Immunohistochemistry}

For immunohistochemistry (IHC) analysis, 3- $\mu$ m paraffin sections were pretreated using a pressure boiler $\left(100{ }^{\circ} \mathrm{C}, 6 \mathrm{~min}\right)$ and stained with antibodies against Topo2a (clone SWT3D1, 1:50), ER (clone 6F11, 1:6), PR (clone 16, 1:100; all from DCS Innovative Diagnostik-Systeme, Hamburg, Germany). HER2 was stained using the Herceptest kit, according to the manufacturer's instructions, and detection of all antibodies was by EnVision+ (Dako, CA, USA) with diaminobenzidine (DAB) as chromogen. Only nuclear staining was considered for Topo2a, ER and PR, whereas positive HER2 assessment required membrane staining. All results were assessed by 2 pathologists $(\mathrm{BH}, \mathrm{MB})$, using the semiquantitative immunoreactive score (IRS) [20] for ER/PR, with a modified cut-off of positivity of IRS $\geq 2$. Quantitative variations between $\mathrm{BC}$ and $\mathrm{mLN}$ were grouped as follows: minor (IRS 1-2), mean (IRS 3-4) and high (IRS $\geq 5$ ) changes of receptor positivity. Discordance was defined as either absolute deviation between the BC and the mLN (positive /negative) or in case of a difference of $\geq 8$ IRS points. Interpretation of HER2 was scored on a scale of 0 to $3+$ (Dako scoring) [21], and equivocal overexpression was defined by $2+$, overexpression by $3+$ with complete membrane staining. As the vast majority of tumor samples had a focality staining score of 1 for Topo $2 \mathrm{a}$, the percentage of positive cells was evaluated in each sample and a cut-off value of $\geq 20 \%$ was identified for Topo2a positivity.

\section{Fluorescence in situ Hybridization}

In all cases with a HER2 score of $2+/ 3+$, fluorescence in situ hybridization (FISH) was performed to detect HER2 and Topo2a amplification [8, 22]. Slides were pretreated $\left(30 \mathrm{~min}, 80^{\circ} \mathrm{C}\right)$ and then incubated in protease buffer $\left(11 \mathrm{~min}, 37^{\circ} \mathrm{C}\right)$, dehydrated in graded alcohol baths and dried in a hybridization machine $\left(3 \mathrm{~min}, 37^{\circ} \mathrm{C}\right)$. Sections were hybridized with a FISH probe combination containing SpectrumOrange LSI HER2 and Topo-IIa and SpectrumGreen LSI CEP-17 using a HYbrite instrument that performs codenaturation and hybridization. The Topo-IIa probe covers $\sim 280 \mathrm{~kb}$, including the entire Topo $2 a$ gene, and the LSI HER2 probe covers $\sim 190 \mathrm{~kb}$, including the entire $\operatorname{erbB} 2$ gene. The CEP-17 probe contains sequences homologous to the D17Z1 satellite repeat sequence. After the probe hybridization mixture was applied, the slides were code- 
natured $\left(3 \mathrm{~min}, 85^{\circ} \mathrm{C}\right)$ and hybridized $\left(18 \mathrm{~h}, 37^{\circ} \mathrm{C}\right)$. After removal of nonspecifically bound FISH probe, the slides were incubated ( $2 \mathrm{~min}$, $74^{\circ} \mathrm{C}$ ) and then air-dried in the dark. $10 \mu \mathrm{l}$ 4,6-diamidino-2-phenylindole (DAPI) was applied to the specimen to allow visualization of the nuclei (FISH from Vysis Inc., IL, USA). Afterwards, the slides were evaluated using a Zeiss Axioscope epifluorescence microscope; the signals were visualized and counted using a DAPI single-band pass filter set to visualize nuclei: orange for SpectrumOrange (LSI) HER2/Topo-IIa and green to visualize SpectrumGreen CEP-17. Signals for each probe were counted in at least 20 tumor cells. A calculated signal ratio LSI/CEP > 2 indicates amplification, and to discriminate low/high amplification, the absolute number of nuclei amplification signals was detected [23]. For low amplification: $\geq 10 \%$ of cell nuclei show $4<\mathrm{x} \leq 10$ signals, ratio LSI/CEP $>2$; and for high amplification: $\geq 10 \%$ of cell nuclei show $>10$ signals.

\section{Chromogenic in situ Hybridization}

Chromogenic in situ hybridization (CISH) for HER2 and Topo2a was performed according to the manufacturer's instructions (ZytoVision, Bremerhaven, Germany) restricted to cases with HER2 IHC $2+/ 3+$. After deparaffinization, heat pretreatment was carried out $\left(20 \mathrm{~min}, 92^{\circ} \mathrm{C}\right)$ and pretreatment enzymes were applied. Then, $15 \mu \mathrm{l}$ SpotLight digoxigeninlabeled HER2 or Topo2a probe (ZytoVision) was applied. The slides were coverslipped and heated at $74^{\circ} \mathrm{C}$ for $5 \mathrm{~min}$, followed by overnight incubation at $37^{\circ} \mathrm{C}$ in a moisturized chamber. A posthybridization wash in $0.5 \times$ standard saline citrate $\left(5 \mathrm{~min}, 75^{\circ} \mathrm{C}\right)$ was performed, followed by blocking endogenous peroxidases in $3 \% \mathrm{H}_{2} \mathrm{O}_{2}(10 \mathrm{~min})$. Incubation with mouse anti-digoxigenin and then polymerized horseradish peroxidase (HRP)-conjugated anti-mouse antibodies was performed (each for $30 \mathrm{~min}$ ). The HER2 and Topo2a probes were visualized using a DAB solution (30 $\mathrm{min}$ ) (ZytoDotCISH implementation kit for Topo2a and ZytoDotSPEC HER2 probe kit for HER2; ZytoVision). Sections were slightly counterstained with hematoxylin, dehydrated in graded ethanol and coverslipped. At least 60 cells were counted per tissue core with a light microscope using a $20 \times$ objective, visualizing gene copies as dark brown or dark blue dots, scattered or in small clusters.

\section{Statistical Methods}

Findings were analyzed by using IBM SPSS for Windows, version 20 (SPSS, Chicago, USA). Discordance of hormone receptor status, HER2 status and Topo2a expression between $\mathrm{BC}$ and mLN was evaluated using Cohen's kappa (к). A p value of less than 0.05 was defined as statistically significant.

\section{Results}

\section{Discordance for ER}

Out of 117 evaluable patients for ER status, positivity was seen in 89 BCs and 92 mLNs. 26 patients $(22.3 \%)$ had a higher IRS score in the primary tumor than in the mLN. Of these, 10 patients $(8.6 \%)$ had a difference of $\leq 2,15(12.8 \%)$ of $3-4$ and $1(0.9 \%)$ of $\geq 6$ IRS points. A lower IRS score in the BC than in the mLN was obtained in $21(18.0 \%)$ patients, with a difference of $\leq 2$ IRS points in 13 patients $(11.1 \%), 3-4$ in $7(6.0 \%)$ patients and $\geq 6$ in $1(0.9 \%)$ patient. 70 patients $(59.8 \%)$ had the same IRS score in BC and mLN. These cases are considered as concordant. The majority of the patients (113/117, 97.4\%) showed concordant ER expression between $\mathrm{BC}$ and $\mathrm{mLN}$. In 3 patients $(2.6 \%)$, the ER status was discordant. When ER-positive tumors in the $\mathrm{mLN}$ were examined, all 3 were negative in the BC (fig. 2).

$\left.\begin{array}{cccc}\text { PT/mLN } & \multicolumn{3}{l}{\text { No.patients (\%) }} \\ \hline \begin{array}{c}\text { ER-status } \\ +/+\end{array} & \mathrm{n}=117 & 89(76.1) & \\ -/- & & 25(21.4) & \\ -/+ & & 3(2.6) & \\ +/- & & 0(0.0) & \end{array}\right\}^{\mathrm{K}=0.925}$

\section{Discordance for $P R$}

The PR status was evaluated in 116 patients. Positivity in BC was seen in 85 patients and positivity in $\mathrm{mLN}$ in 83 patients. A higher IRS score in the BC compared to the $\mathrm{mLN}$ was obtained in 25 patients $(21.5 \%), 10(8.6 \%)$ had $\leq 2,14(12.0 \%)$ had 4 IRS points of difference, and a difference of $\geq 6$ IRS points was seen in 1 patient $(0.9 \%)$. Of the 10 patients $(8.6 \%)$ with lower IRS scoring in the BC than in the mLN, 5 patients $(4.3 \%)$ had a difference in IRS score of $\leq 2,4$ patients $(3.4 \%)$ had a difference of 4 , and 1 patient $(0.9 \%)$ of 6.81 patients $(69.8 \%)$ had the same IRS score in the BC and the mLN; analogously to the ER evaluation, these cases are considered as concordant (112 patients, 96.6\%). Discordance was shown in 4 patients $(3.4 \%)$, whereas 3 patients had a PR-positive BC and 1 patient $(0.9 \%)$ a PR-negative $\mathrm{BC}$, each with discordant $\mathrm{mLN}$ (fig. 2).

\section{Discordance for HER2}

Of the patients, 117 were included for HER2 IHC evaluation. The percentage of HER2-equivocal and -positive BC was $23.1 \%$ (11 patients with $2+, 16$ patients with $3+$ ). With regard to the mLNs, the HER2 status was equivocal or positive in 29 patients $(24.8 \%)$. Of the total of 117 patients, $113(96.6 \%)$ revealed a concordance between the $\mathrm{BC}$ and the corresponding mLN. Only in 4 cases $(3.4 \%)$ the HER2 receptor status did not match. Within the subgroup of HER2-equivocal/-positive $\mathrm{BC}, 1$ patient $(0.9 \%)$ was negative in the $\mathrm{mLN}$. 3 tumors (2.6\%) that were HER2 negative in BC showed HER2 equivocality $(\mathrm{n}=2,2+)$ or HER2 positivity $(\mathrm{n}=1,3+)$ in the $\mathrm{mLN}$ (fig. 3). All patients who had a discordant result when BC and mLN were compared had a difference in the range of only 1 unit on the intensity scale. All 27 (23.1\%) patients with 


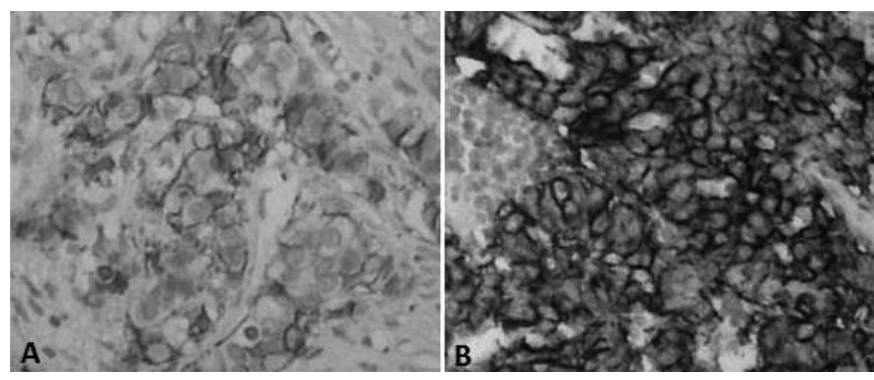

Fig. 3. Primary breast carcinoma $(\mathbf{A}, \times 40)$ with negative $(1+)$ HER2 status and matched $\mathrm{mLN}$ that was positive $(3+)$ for HER2 immunohistochemical analysis $(\mathbf{B}, \times 40)$.

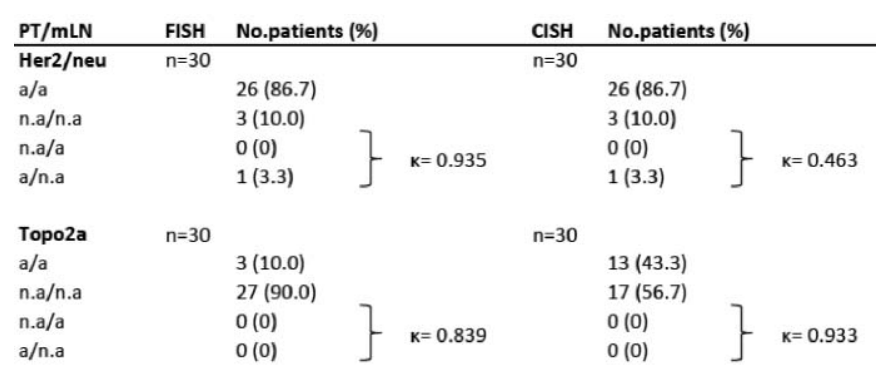

Fig. 4. Comparison of HER2 and Topo2a status in 117/116 cases of primary BC and $\mathrm{mLN}$ by FISH and CISH. PT, primary tumor; $\mathrm{mLN}$, metastatic lymph node; FISH, fluorescence in situ hybridization; CISH, chromogenic in situ hybridization; HER2, ErbB2 status; Topo2a, topoisomerase 2a status; a, amplification; n.a, no amplification; \}, discordant cases; $\kappa$, Cohen's kappa.

HER2-equivocal or -positive BC and 3 (2.6\%) discordant cases with HER2-equivocal or -positive $\mathrm{mLN}$ were included in the FISH and CISH examinations. In most of the 30 cases (26 patients, $22.2 \%$ ), the results were concordant with the IHC score evaluation $(\mathrm{p}<0.001)$; only 1 patient $(0.9 \%)$ with a HER2-equivocal primary tumor with a score of $2+$ was negative in the mLN by FISH and CISH (figs. 2 and 4).

\section{Discordance for Topo2a}

Topo2a evaluation was possible in 116 patients with IHC. $8(6.9 \%)$ patients were Topo2a positive in the BC and $8(6.9 \%)$ patients were also Topo2a positive in the $\mathrm{mLN}$, whereas the main part of the patients (108 patients, $93.1 \%$ ) was negative for Topo2a in the primary tumor and 108 patients $(93.1 \%)$ were Topo2a negative in the $\mathrm{mLN}$. Overall, for 112 patients (96.6\%), the Topo2a status matched in the BC and the mLN. The subgroup of patients with Topo2a-positive $\mathrm{BC}$ showed a percentage of discordance of $1.7 \%$ (2 patients). Regarding Topo2a positivity in the mLN, 2 patients $(1.7 \%)$ were negative in the BC. So, 4 discordant cases $(3.4 \%)$ were recorded in all 116 patients. The previously mentioned collective of 30 patients with IHC HER2 2+ or 3+ scoring (27 BC, $3 \mathrm{mLN}$ ) were examined by FISH and CISH. Concordant cases showed FISH amplification in 2 patients $(1.7 \%)$ and positive CISH in 12 patients $(10.5 \%)$, whereas 1 FISH $(0.9 \%)$ and $1 \mathrm{CISH}$ amplification $(0.9 \%)$ were registered for the discord- ant cases. The amplification rate in FISH and CISH showed a percentage of concordance of $100 \%$ between the $\mathrm{BC}$ and the matched $\mathrm{mLN}$ ( $\mathrm{p}<0.001$; figs. 2 and 4$)$.

\section{Discussion}

In this retrospective study, we used paraffin-embedded BC tissue from 119 patients (primary diagnosed) with at least 1 ipsilateral axillary $\mathrm{mLN}$. IHC was used to analyze ER, PR, HER2 and Topo2a in every BC and mLN. In addition, HER2 and Topo2a amplification was evaluated by FISH and CISH in all samples with a HER2 score of $2+/ 3+$ by IHC.

Discordant results were seen in $2.6 \%$ (ER), $3.5 \%$ (PR), $3.4 \%$ (HER2), and $3.5 \%$ (Topo2a) by IHC, but this was not significant.

In the literature, discordance rates for hormone receptors between $18-54 \%$ have been reported [11-13]. Sari et al. [24] described a discordance of $36 \%$ for ER and $54.2 \%$ for PR in a cohort of 78 patients between $\mathrm{BC}$ and paired recurrent and/or metastatic lesions. They found more changes from negative to positive $(50 \% ; \mathrm{n}=8)$ than from positive to negative $(27.9 \% ; \mathrm{n}$ = 17). In our cohort, we saw the same phenomenon for the ER (all 3 discrepant cases were negative in the $\mathrm{BC}$ and positive in the $\mathrm{mLN}$ ), but this was not seen for the PR; the shift from negative to positive was only seen in 1 case $(0.9 \%)$, but the shift from positive to negative was detected in $3(2.6 \%)$ cases.

Discordance rates between 0-34\% have been reported for HER2 expression between invasive BC and its paired recurrent tumor $[11,13-17,19]$. Some studies have shown that discordance in the HER2 status occurs more frequently in distant metastases than in locoregional metastases $[18,25]$. Santinelli et al. [18] observed HER2 discordance in $6.7 \%$ of synchronous LNs, $13.3 \%$ of local recurrences and $28.6 \%$ of metachronous distant metastases, compared with the primary breast carcinomas. In our study, we detected a discordance rate of $2.6 \%$ in synchronous mLNs.

Due to the recent discussion regarding coamplification of the Topo2a gene in HER2-amplified BCs, we examined the Topo2a expression with IHC, FISH and CISH in the BC and the ipsilateral $\mathrm{mLN}$. In approximately $7 \%$ of all cases, Topo2a positivity was found for the $\mathrm{BC}$ and the $\mathrm{mLN}$ tissue by IHC. The discordance rate was $3.4 \%$ of all 116 cases. However, using FISH and $\mathrm{CISH}$, we found a complete concordance $(100 \%)$ of the Topo2a and HER2 status between the BC and the corresponding axillary LN. Comparing FISH and CISH, our results show a higher sensitivity with CISH in detecting amplification of Topo2a. A possible explanation for this might be intratumoral heterogeneity of the Topo2a alteration in BCs and/or different lengths of the DNA probes hybridizing to the Topo2a region, as recently described [26]. Press et al. [8] demonstrated in their study that women whose cancers have HER2 and Topo2a coamplification experience equiva- 
lent disease-free, recurrence-free and overall survival outcomes, regardless of treatment with a trastuzumab-containing regime or an anthracycline-based regimen without trastuzumab. They postulate that BCs containing both alterations benefit equally when treated with either trastuzumab or anthracyclines; however, they appear to receive no additional benefit from combining trastuzumab with anthracyclines. So they conclude that the incremental benefit from anthracyclines reported for $\mathrm{BC}$ is restricted to HER2-positive patients and demand that anthracycline-based adjuvant therapies, with their attendant short- and long-term risks, should only be considered for the approximately $8 \%$ of human $\mathrm{BC}$ cases with HER2 and Topo2a coamplification, and only in patients who do not receive a HER2-targeted therapy.

Treatment-induced selection was presumed by Kunitomo et al. [27] in their report demonstrating an outgrowth of HER2-negative cells in metastatic sites following the obliteration of HER2-positive tumor cells by trastuzumab. Xiao et al. [28] examined in their retrospective study the stability of the HER2-positive status during disease progression and the impact of trastuzumab treatment on the loss of the HER2-positive status, by comparing the HER2 status between primary and paired metastatic tumors in patients with and without intervening trastuzumab treatment. They found that positiveto-negative HER2 status conversion does occur during disease progression. Based on their findings, however, trastuzumab treatment does not seem responsible for the loss of the HER2-positive status in metastatic breast carcinomas. They also revealed no evidence that an ER status change was related to trastuzumab treatment. In our study, treatment effects could not have been an issue because of the fact that $\mathrm{BC}$ and $\mathrm{mLN}$ tissues were collected during the same operation procedure, without any therapy influence.

Our analysis has the following strengths: Firstly, for all procedures, we produced new hybrid blocks with representative tumor areas from the original tumor and the mLN tissue. This ensured a crucial minimization of the technical error rate by using identical conditions for the $\mathrm{BC}$ and the corresponding $\mathrm{mLN}$. The independent assessment of the $\mathrm{mLN}$ in a separate passage from the BC guaranteed an unaffected evaluation of both tissues. Secondly, we used various methods for the detection of HER2 and Topo2a (IHC, FISH, CISH). So we were able to compare the results generated by different techniques. Technical errors were ruled out by repeating the dyeing of all discordant cases and staining evaluation of all slides by 2 independent pathologists. There was an absolute inter-observer concordance in the interpretation of the results. In order to improve the accuracy of receptor testing in invasive $\mathrm{BC}$ and its utility as a predictive marker, the American Society of Clinical Oncology-College of American Pathologists (ASCOCAP) guidelines were considered for HER2 and hormonal receptor testing [21, 29].

A disadvantage of our study is the retrospective approach, which may not allow any statement to the relevance of therapy in relation to this setting. Moreover, in the study, only $1 \mathrm{mLN}$ was examined for the mentioned properties. We have no information as to what extent the differences between the examined parameters would differ between multiple affected LNs of the same patient.

Taken together, we detected discordant rates of the biological markers examined between $\mathrm{BC}$ and $\mathrm{mLN}$ that were not significant at the sample size provided. Whether these differences affecting patient therapy will have an impact on survival can only be clarified in a prospective trial. At present, the simultaneous determination of these parameters in $\mathrm{BC}$ and LN is not a standard approach. Further studies evaluating this fundamental question are desirable.

\section{Disclosure Statement}

The authors declare no conflicts of interest.

\section{References}

1 Thike AA, Chng MJ, Fook-Chong S, Tan PH: Immunohistochemical expression of hormone receptors in invasive breast carcinoma: correlation of results of $\mathrm{H}$-score with pathological parameters. Pathology 2001;33:21-25.

2 Early Breast Cancer Trialists' Collaborative Group (EBCTCG): Effects of chemotherapy and hormonal therapy for early breast cancer on recurrence and 15-year survival: an overview of the randomised trials. Lancet 2005;365:1687-1717.

3 Pritchard KI, Shepherd LE, O'Malley FP, Andrulis IL, Tu D, Bramwell VH, Levine MN: HER2 and responsiveness of breast cancer to adjuvant chemotherapy. N Engl J Med 2006;354:2103-2111.

4 Placido S, Carlomagno C, Laurentiis M, Bianco AR: c-erbB2 expression predicts tamoxifen efficacy in breast cancer patients. Breast Cancer Res Treat 1998;52:55-64.

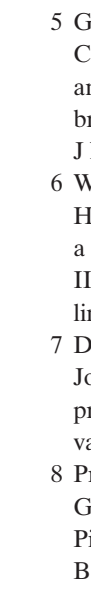

Gennari A, Sormani MP, Pronzato P, Puntoni M, Colozza M, Pfeffer U, Bruzzi P: HER2 status and efficacy of adjuvant anthracyclines in early breast cancer: a pooled analysis of randomized trials. J Natl Cancer Inst 2008;100:14-20.

6 Withoff S, Keith WN, Knol AJ, Coutts JC, Hoare SF, Mulder NH, de Vries EG: Selection of a subpopulation with fewer DNA topoisomerase II alpha gene copies in a doxorubicin-resistant cell line panel. Br J Cancer 1996;74:502-507.

7 Depowski PL, Rosenthal SI, Brien TP, Stylos S, Johnson RL, Ross JS: Topoisomerase IIalpha expression in breast cancer: correlation with outcome variables. Mod Pathol 2000;13:524-547.

8 Press MF, Sauter G, Buyse M, Bernstein L, Guzman R, Santiago A, Villalobos IE, Eiermann W, Pienkowski T, Martin M, Robert N, Crown J, Bee V, Taupin H, Flom KJ, Tabah-Fisch I, Pauletti G, Lindsay M, Riva A, Slamon DJ:
Alteration of topoisomerase II-alpha gene in human breast cancer: association with responsiveness to anthracycline-based chemotherapy. J Clin Oncol 2011;29:859-867.

9 Schrohl A, Holten-Andersen M, Sweep F, Schmitt M, Harbeck N, Foekens J, Brünner N; European Organisation of Research and Treatment of Cancer (EORTC) Receptor and Biomarker Group: Tumor markers: From laboratory to clinical utility. Mol Cell Proteomics 2003;2:378387.

10 Cummings MC, Walsh MD, Hohn BG, Bennett IC, Wright RG, McGuckin MA: Occult axillary lymph node metastases in breast cancer do matter: results of 10-year survival analysis. Am J Surg Pathol 2002;26:1286-1295.

11 Guarneri V, Giovannelli S, Ficarra G, Bettelli S, Maiorana A, Piacentini F, Barbieri E, Dieci MV, D'Amico R, Jovic G, Conte P: Comparison of 
HER-2 and hormone receptor expression in primary breast cancers and asynchronous paired metastases: impact on patient management. Oncologist 2008;13:838-844.

12 Broom RJ, Tang PA, Simmons C, Bordeleau L, Mulligan AM, O'Malley FP, Miller N, Andrulis IL, Brenner DM, Clemons MJ: Changes in estrogen receptor, progesterone receptor and Her-2/neu status with time: discordance rates between primary and metastatic breast cancer. Anticancer Res 2009;29:1557-1562.

-13 Simmons C, Miller N, Geddie W, Gianfelice D, Oldfield M, Dranitsaris G, Clemons MJ: Does confirmatory tumor biopsy alter the management of breast cancer patients with distant metastases? Ann Oncol 2009;20:1499-1504.

14 Gancberg D, Di Leo A, Cardoso F, Rouas G, Pedrocchi M, Paesmans M, Verhest A, BernardMarty C, Piccart MJ, Larsimont D: Comparison of HER-2 status between primary breast cancer and corresponding distant metastatic sites. Ann Oncol 2002;13:1036-1043.

15 Gong Y, Booser DJ, Sneige N: Comparison of HER-2 status determined by fluorescence in situ hybridization in primary and metastatic breast carcinoma. Cancer 2005;103:1763-1769.

16 Zidan J, Dashkovsky I, Stayerman C, Basher W, Cozacov C, Hadary A: Comparison of HER-2 overexpression in primary breast cancer and metastatic sites and its effect on biological targeting therapy of metastatic disease. Br J Cancer 2005;93:552-556.

-17 Tapia C, Savic S, Wagner U, Schönegg R, Novotny H, Grilli B, Herzog M, Barascud AD, Zlobec I, Cathomas G, Terracciano L, Feichter G, Bubendorf L: HER2 gene status in primary breast cancers and matched distant metastases. Breast Cancer Res 2007;9:28-31.

18 Santinelli A, Pisa E, Stramazzotti D, Fabris G: HER-2 status discrepancy between primary breast cancer and metastatic sites. Impact on target therapy. Int J Cancer 2008;122:999-1004.

19 Lower EE, Glass E, Blau R, Harman S: HER-2/ neu expression in primary and metastatic breast cancer. Breast Cancer Res Treat 2009;113:301-306.

20 Remmele W, Stegner HE: Recommendation for uniform definition of an immunoreactive score (IRS) for immunohistochemical estrogen receptor detection (ER-ICA) in breast cancer tissue. Pathologe 1987;8:138-140.

21 Wolff AC, Hammond MEH, Schwartz JN, Hagerty KL, Allred DC, Cote RJ, Dowsett M, Fitzgibbons PL, Hanna WM, Langer A, McShane LM, Paik S, Pegram MD, Perez EA, Press MF, Rhodes A, Sturgeon C, Taube SE, Tubbs R, et al.: American Society of Clinical Oncology/College of American Pathologists guideline recommendations for human epidermal growth factor receptor 2 testing in breast cancer. J Clin Oncol 2007;25:118-145.

22 Järvinen TA, Tanner M, Rantanen V, Bärlund M, Borg A, Grénman S, Isola J: Amplification and deletion of topoisomerase IIalpha associate with ErbB-2 amplification and affect sensitivity to topoisomerase II inhibitor doxorubicin in breast cancer. Am J Pathol 2000;156:839-847.

23 Pauletti G, Godolphin W, Press MF, Slamon DJ: Detection and quantitation of HER-2/neu gene amplification in human breast cancer archival material using fluorescence in situ hybridization. Oncogene 1996;13:63-72.

24 Sari E, Guler G, Hayran M, Gullu I, Altundag K, Ozisik Y: Comparative study of the immunohisto- chemical detection of hormone receptor status and HER-2 expression in primary and paired recurrent/ metastatic lesions of patients with breast cancer. Med Oncol 2011;28:57-63.

25 Regitnig $\mathrm{P}$, Schippinger W, Lindbauer M, Samonigg H, Lax SF: Change of HER-2/neu status in a subset of distant metastases from breast carcinomas. J Pathol 2004;203:918-926.

26 Varga Z, Moelans C, Zuerrer-Hardi U, Ramach C, Behnke S, Kristiansen G, et al.: Topoisomerase 2A gene amplification in breast cancer. Critical evaluation of different FISH probes. Breast Cancer Res Treat 2011;15:1-7.

27 Kunitomo K, Inoue S, Ichihara F, Kono K, Fujii H, Matsumoto Y, Ooi A: A case of metastatic breast cancer with outgrowth of HER2-negative cells after eradication of HER2-positive cells by humanized anti-HER2 monoclonal antibody (trastuzumab) combined with docetaxel. Hum Pathol 2004;35:379-381.

28 Xiao C, Gong Y, Han EY, Gonzalez-Angulo AM, Sneige N: Stability of HER2-positive status in breast carcinoma: a comparison between primary and paired metastatic tumors with regard to the possible impact of intervening trastuzumab treatment. Ann Oncol 2011;22:1547-1553.

29 Hammond MEH, Hayes DF, Dowsett M, Allred DC, Hagerty KL, Badve S, Fitzgibbons PL, Francis G, Goldstein NS, Hayes M, Hicks DG, Lester S, Love R, Mangu PB, McShane L, Miller K, Osborne CK, Paik S, Perlmutter J, et al.: American Society of Clinical Oncology/College of American Pathologists guideline recommendations for immunohistochemical testing of estrogen and progesterone receptors in breast cancer. Arch Pathol Lab Med 2010;134:48-72. 